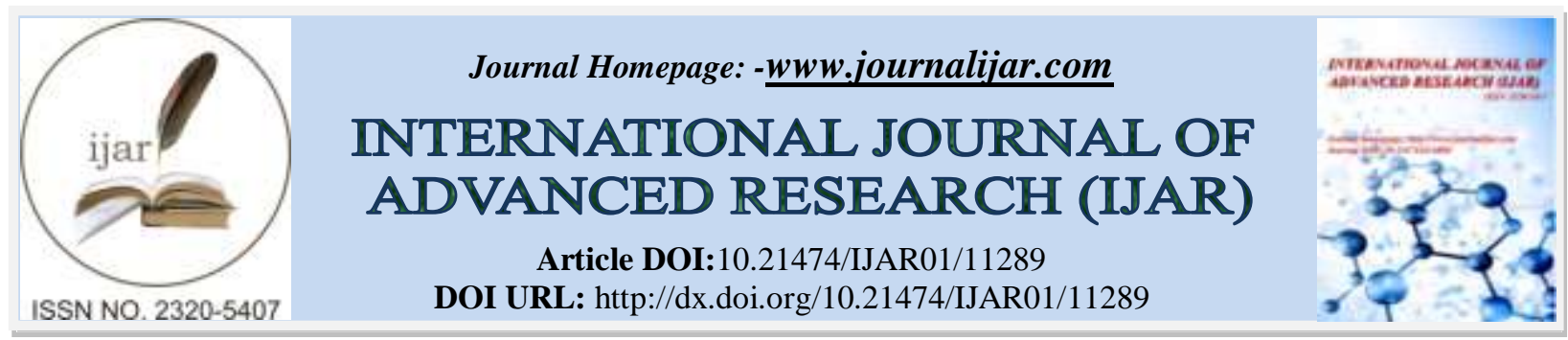

RESEARCH ARTICLE

\title{
EFFECT OF SOME OPERATION CONDITIONS FOR TRACTOR ON SOIL COMPACTION UNDER DIFFERENT AGRICULTURE SYSTEMS - RAS SUDR - SOUTH OF SINAI
}

Meselhy A.A and I.M.M Khater

Agricultural Mechanization Unit, Department of Soil Conservation, Desert Research Center- Egypt.

\section{Manuscript Info}

Manuscript History

Received: 05 May 2020

Final Accepted: 10 June 2020

Published: July 2020

Key words:-

Conservation Agriculture Systems, Soil Compaction, Soil Moisture Content, Sorghum Yield Tire Air Pressure, Tractor Forward Speed, Tractor Wheel Traffic

\section{Abstract}

One of the most negative effects of the using agricultural machinery under inappropriate operation conditionsis the soil compaction resulting from traffic of tractor wheel on the soil surface during the performance of various agricultural processes. The accumulation of this effect leads to soil degradationand lack of sustainable agricultural development.Therefore, this research aims to reduce soil compaction, prevent soil degradation and achievement sustainable agricultural development by study the effect of some operations conditions for tractor (soil moisture content, forward speed and tires air pressure) under different agriculture systems (traditional agriculture and conservation agriculture). So that the field experiment conducted in Ras Sudr, South of Sinai Governorate (sandy loam soil) at three levels of soil moisture content $(15 \%, 20 \%$ and $25 \%$ ), three levels of tractor forward speed $(3,5$ and 7$) \mathrm{km} / \mathrm{h}$ and three levels of tires air pressure $(50,100$ and 150$) \mathrm{kPa}$. The measurements were fuel consumption, tractor wheel slippage, rolling resistance, soil bulk density, soil penetration resistance, average infiltration rate, soil surface sinkage, soil layer deformation and sorghum yield (fresh forage). The results showed that significant effect of all study treatments on soil compaction which, resulting from traffic of the tractortires under two agriculture systems. The results showed that, conservation agriculture system achieved the largest decreasing of power requirements and more resistance to soil compaction compared to the traditional agriculture system. Where, conservation agriculture system decreased fuel consumption, tractor wheel slippage, rolling resistance and soil surface sinkage about of $72 \%, 75 \%, 38 \%$ and $57 \%$ respectively, compared to traditional agriculture system. The results indicated to, soil bulk density and soil penetration resistance increased in both of two agriculture systems in traffic zones compared to no-traffic zones but these increasing in the traditional agriculture system were greater than in the conservation agriculture system. Where the increasing of soil bulk density and soil penetration resistance in traffic zones compared to notraffic zones were about of $37 \%$ and $96 \%$ respectively, for traditional agriculture system and about of $15 \%$ and $31 \%$ respectively, for conservation agriculture system. In general, the results showed that average infiltration rate decreased in traffic zones compared to notraffic zones for two agriculture systems, but the decreasing in 
traditional agriculture system was greater than conservation agriculture system. Where, the decreasing of average infiltration rate in traffic zones was about of $62 \%$ compared to no-traffic zones for traditional agriculture system and about of 39\% for conservation agriculture system. The soil layer deformation measured for three soil layers $(0: 7$, 7:14 and 14:21) $\mathrm{cm}$ and the results showed that all soil layers deformation increased in traffic zones but the soil surface layer was the largest increasing in deformation compared to the deeper layers for both of two agriculture systems. The average deformation of the soil layers in conservation agriculture system was lower than in the traditional agriculture system about of 55\%. In general, sorghum crop yield affected by increasing soil compaction and its productivity decreased about of $46 \%$ and $41 \%$ in the traffic zones of tractor tires compared to no-traffic zones for traditional agriculture system and conservation agriculture system respectively. According to the experimental results, the best treatment, which achieved the high resistance to the compaction and the greatest yield of the sorghum crop, was the moisture content $15 \%$, tractor forward speed $7 \mathrm{~km} / \mathrm{h}$ and tire air pressure $50 \mathrm{kPa}$. This is the best treatment in the both of agriculture systems but the conservation agriculture system was the best to resistance the soil compaction. Despite the increasing in the crop yield in the traditional agricultural system compared to the conservation agriculture system, about of 5\% during one agricultural season, the yield in the conservation system is expected to increase by continuous application to more than one agricultural season.

Copy Right, IJAR, 2020, All rights reserved.

\section{Introduction:-}

Recently, heavier and more powerful tractors and machines used on farms throughout the world. Aiming to reduce the human labor and a corresponding increase in farm size with a need to increase individual operator productivity. Some of the most serious problems are resulted by the soil deformation, compaction and destruction of established soil structure. The degree of soil compaction refers to the axle load. Vehicles with high axle loads have reduced yield crop, increased cone penetration resistance and increased bulk density (Swan and Voorhees, 1987). McKyes, (1985) stated that soil compaction could be caused by natural phenomena such as rainfall impact, soaking, internal water tension and the like. On the other hand, artificial soil compaction occurs by tractors and agricultural machines. Hettiaratchi, (1987) reported that the degree of compaction depends on the following: soil mechanical strength, which influenced by intrinsic soil properties such as texture, soil organic matter content and water content. Tullberg et al., (1990) estimated that over $30 \%$ of ground area is trafficked by the tires of heavy machinery in zero tillage systems (one pass at sowing). Under minimum tillage (2-3 passes), the percentage is likely to exceed $60 \%$ and in conventional tillage (multiple passes) it would exceed $100 \%$ during one cropping cycle. Flowers and Lal, (1998) discuss that the depth of the compaction varies widely from 10 to $60 \mathrm{~cm}$ but it is more obvious on topsoil (around 10 $\mathrm{cm})$. Abu-Hamdeh and Reeder, (2003) proved that soil compaction under tractors and agricultural machines is of special concern because weights of these machines have been increased dramatically in the last decades. Pagliai et al., (2003) showed that soil compaction is one of the most important factors responsible for soil physical degradation. IIRR and ACT, (2005) noted that conservation agriculture (CA) is an approach to agricultural management based on three principles. The first: Minimum soil disturbance Zero tillage, the second: Retention of crop residues or other soil surface cover many definitions of CA use $30 \%$ permanent organic soil cover as the minimum and the third: Use of crop rotations which helps reduce build-up of weeds.

Allison and Moodie, (1965) stated that soil penetration resistance need to compare with different soil water contents because, soil water changes significantly affect soil penetration resistance, it is almost difficult to determine the penetration resistance differences caused by water content or treatment. Amir et al., (1976) presented an equation that made it possible to predict the amount of soil compaction as a function of contact pressure and soil moisture. Hill and Meza-Montalvo, (1990) reported that frequent traffic of machinery and equipment, in irrigated field causes a breakdown of soil structure in the topsoil layer, and considerable compaction of the lower layers. As a result, it is 
difficult to prepare a good seedbed, which affects germination, and consequently irregular stands obtained. Through the years, the intensive use of the agricultural machinery without moisture control has been causing dissemination of the soil compaction consequently; productivity of land in such areas is significantly affected. Kirby and Kirchhoff, (1990) found that soil compaction from high axle loads increases when the soil is wet because wet soil has reduced strength. Carter et al., (1991) suggested that if farm operations performed when soil is dry to very dry, soil compaction minimized significantly but caused increase energy consumption. Meek et al., (1992) found that tire pressure of $200 \mathrm{kPa}$ along with a wheel mass of $2724 \mathrm{~kg}$ applied at moisture contents near field capacity resulted in a bulk density of $1.92 \mathrm{~g} / \mathrm{cm}^{3}$ compared with a value of $1.67 \mathrm{~g} / \mathrm{cm}^{3}$ for no-traffic. Sonae and Van Ouwerkerk (1994) reported that soil water content is the most important factor influencing soil compaction processes. At all compaction levels, the penetration resistance increases with decreasing soil water content. Ohu et al., (1994) investigated that soil deformation increases with moisture content. Silva et al., (2000) mentioned that soil compaction increased with increasing soil moisture content. Hamza and Anderson, (2005) suggested that if farm operations performed when soil is dry to very dry, soil compaction minimized significantly. However, caused increase in energy consumption.

Bolling, (1986) found that an increasing in tractor forward speed on the soil causes reduced soil compaction. Therefore, seedbed preparation should be done at high speed to reduce soil compaction. Grahn, (1991) stated that soil surface sinkage decreases with increasing forward speed. Carman, (2002) found that bulk density, penetration resistance, rolling resistance, soil surface sinkage and soil layer deformation decreases with increasing forward speed because increased forward velocity decreasing contact duration. Soil compaction decreased with increasing soil depth.

Alakukku et al., (2003) recommendations that ground contact stress reduced by increasing the ground contact area, by using tracks instead of tires or by using more tires or by reducing tire inflation pressure. Way and Kishimoto, (2004) reported that reductions in soil compaction and disturbance resulting from operating at lower tire inflation pressures. Arvidsson and Keller, (2007) studied the effect of wheel loads (11,15 and $33 \mathrm{kN}$ ) at inflation pressures of 50,70 and $150 \mathrm{kPa}$ on soil stress, found that the tire inflation pressure has a large influence on soil stresses measured at $10 \mathrm{~cm}$ depth, but has very little influence in the subsoil $(30 \mathrm{~cm}$ and deeper).

Gupta et al., (1985) tested some soils and found that the sandy clay loam soil had the highest bulk density when compacted with sandy loam soil under standard conditions. Meek et al., (1988) reported that bulk density of a sandy loam soil reduced by tillage. However, when a compaction force applied by wheel traffic, bulk density and consequent soil compaction will increase to values that depends on factors such as soil moisture and wheel load. Jakobsen and Dexter, (1989) reported that tractor and machine weight, tire pressure and soil water at the time of traffic are some of the factors determinant for soil compaction and resulting changes in the plant-root environment. Other factors such as repetition of passes and wheel slip and forward velocity may be of importance as well. Carter, (1990) mention that soil penetration resistant, bulk density and pore size distribution have been used for determination of soil compaction. Busscher, (1990) showed that the resistance of soil penetration might vary rapidly depending on the structure and texture of soil. Singh el al., (1992) stated that the maximum value of bulk density, which considered unusable by plants, is $2.1 \mathrm{~kg} / \mathrm{m}^{3}$ in any type of soil. Mead et al., (1992) found that bulk density of the $0-75 \mathrm{~mm}$ soil layer increased from $1.55 \mathrm{~g} / \mathrm{cm}^{3}$ to $1.70 \mathrm{~g} / \mathrm{cm}^{3}$ when rolled with a rubber tire roller. Bailey et al., (1993) stated that increased dynamic load at a constant tire inflation pressure caused increased soil stress and bulk density. Wheel traffic significantly affected the soil compaction and soil physical properties. Raper and Reeves, (2007) experimentally determined the differences in soil bulk density and cone index (CI) obtained from various interactions of surface tillage, subsoiling, and controlled traffic in a corn-soybean farm and reported that for trafficked row middle, non-trafficked row middle and in-row position. CI almost increased in topsoil (i.e. up to about $20 \mathrm{~cm}$ depth) and decreased in the subsoil level $(20-55 \mathrm{~cm})$. Ansorge and Godwin, (2008) investigated the effects of various wheel loads, tire inflation pressures and number of passes on soil physical change in a controlled laboratory condition measuring penetration resistance and dry bulk density. Patel and Mani, (2011) carried out a field investigation on sandy loam soil to quantify subsoil compaction at ranged wheel loads and multiple passes in terms of bulk density and penetration resistance.

Bauder et al., (1981) showed that the physical conditions of a soil measured largely by monitoring its bulk density, infiltration rate and hydraulic conductivity. Those in turn related to pore size distribution and continuity. Increase in bulk density correlated to an increase in resistance to penetration and a decrease in infiltration rate. Patel and Singh, (1981) reported that increase in bulk density correlated to an increase in resistance to penetration and a decrease in 
infiltration rate. Marsili et al., (1998) stated that soil compaction with farm machinery decreased the soil infiltration rate of the cultivated soils. Kulli et al., (2003) reported that soil compaction decreases water infiltration. Hamza and Anderson, (2003) reported that water infiltration rate used to monitor soil compaction status, especially of the top soil. Water infiltrates un-compacted soil that have well-aggregated soil particles much faster than massive, structureless soils.

Abebe et al., (1989) mention that nearly all studies dealing with soil sinkage due to multiple passes of wheels (multiple loadings) have been experimental. Carman, (1994) reported that an increase of approximately $86 \%$ in tire load caused sinkage to increase by $47 \%$. The load from 7.7 to $13.5 \mathrm{kN}$ increased the sinkage from 53 to $82 \mathrm{~mm}$. Abu-Hamdeh and Reeder, (2003) showed that one of the most important causes of soil compaction is soil sinkage imposed by wheels or tracks. Zeleke et al., (2007) proved that increased load results in increased soil sinkage. Botta et al., (2009) mentioned that the most obvious visual indicator of topsoil compaction is sinkage affected by agricultural tractor and machinery's traffic on the soil. The sinkage will be principally related with initial soil condition, soil moisture content, load and traffic intensity.

Phillips and Kirkham, (1962) reported that corn yield reductions of $10 \%$ to $22 \%$ due to compaction. For each 1 $\mathrm{kg} / \mathrm{m}^{3}$ increase in bulk density, a decrease in maize grain yields of $18 \%$ relative to the yield on a no-compacted plot. Increased soil compaction can reduce yields in potatoes of up to $22 \%$ and decrease wheat growth. These results illustrate the potential for compaction to depress crop yields. Extremely dense soil impedes root growth and thereby limits water consumption of plants. Feldman and Domier, (1970) stated that increased soil compaction could reduce yields of wheat crop up to $22 \%$. Carman et al., (1992) showed that the effect of soil compaction on crop growth include reduced seed emergence and root extension, limited water and nutrient uptake. Lal (1996) reported that soil compaction caused reductions in crop yields are $20 \%$ in soybeans, $30 \%$ in oats, and $25 \%$ in maize. Arvidsson, (2001) showed that the compaction treatment significantly decreased yield crop, increased cone penetration resistance and increased dry bulk density. Wheel traffic of agricultural prime movers well recognized as a major contributor to detrimental soil compaction. Horn et al., (2001) reported that operating with low-pressure tires could significantly decrease soil compaction and increase crop yield while high tire inflation pressure increases soil compaction. Botta et al., (2009) showed that the relation between soil compaction and cropping system are important inputs for effective management of soil physical condition to improve crop production.

Therefore, the main objective of this study was to determine the effect of some tractor operation factors (soil moisture content, tractor forward speed and tire air pressure) and agriculture systems (traditional system and conservation system) on the soil compaction which resulting from tractor traffic, power requirements and sorghum crop yield.

\section{Materials And Methods:-}

The present study was carried out in Ras Sudr, South Sinai Governorate (latitude: $29^{\circ} 37^{\prime} 26^{\prime \prime}$ N, longitude: $32^{\circ} 42^{\prime}$ $43^{\prime \prime} \mathrm{E}$ and the elevation from sea surface $=36.2 \mathrm{~m}$ ) in summer season $(2018)$. The texture of experiment soil sandy loam containing a high percentage of sand (Coarse sand 12.3\% - Fine sand 58.7\%), but having enough silt (19.7\%) and clay $(9.3 \%)$ to make it somewhat coherent. Some chemical properties of the soil and well irrigation water were measured where, $\left(\mathrm{CaCO}_{3} 46.1 \%\right)$, (O.M 0.43\%), (pH 7.76 for soil and 7.89 for Irrigation water) and (E.C $10.5 \mathrm{ds} / \mathrm{m}$ for soil and $4.8 \mathrm{ds} / \mathrm{m}$ for Irrigation water). Bulk density for bare soil was $1.62 \mathrm{~g} / \mathrm{cm}^{3}$.

\section{Implements Specifications:}

\section{The seeder:}

Specifications of seeder, which was used for planting sorghum seeds in rows consists of ten tubes with $180 \mathrm{~cm}$ working width and the mass of $360 \mathrm{~kg}$.

\section{The chisel plow:}

The chisel plow, which used in this study, was mounted type. It has seven shanks arranged in two rows. Mass of plough $225 \mathrm{~kg}$. The type of blades was the shovel share (double acting). The dimensions of the shovel share were $8 \mathrm{~cm}$ width, $34 \mathrm{~cm}$ curvature length and $28 \mathrm{~cm}$ curvature radius.

\section{The tractor:}

Specifications of tractor illustrated in Table (1): 
Table 1:- Specifications of tractor.

\begin{tabular}{|l|l|}
\hline Tractor BELARUS Diesel engine - Model & $\mathrm{D}-243.1$ \\
\hline Net rated power & $90 \mathrm{hp}(66 \mathrm{~kW})$ at 2200 r.p.m \\
\hline Number of cylinders & 4 cylinders \\
\hline Weight, kg & 3460 \\
\hline Max. trailing, kg & 8000 \\
\hline Power take-off shaft & $540-1000 \mathrm{rpm}$ \\
\hline Tires & \\
Front & $9.5-20$ \\
Rear & $15.5-38$ \\
\hline Distance between wheels & \\
Front, mm & $1350-1850$ \\
Rear, mm & $1450-2200$ \\
\hline
\end{tabular}

\section{Experimental Procedure:}

Two experiments were carried out. The first experiment for traditional agriculture system which included tillage operation by chisel plow seven blades using in two passes at $20 \mathrm{~cm}$ tillage depth followed by planting operation by seeder machine and the second experiment for conservation agriculture system which involved no-tillage (directplanting) treatment using seeder machine for direct-planting without tillage. Each one of them having an area of about one hectare established as split-split plots in three replicates. Involved soil moisture content as main plots includes three levels $(15 \%, 20 \%$ and $25 \%)$. Each main plot includes sub plots, which involved three levels of tractor forward speed (3,5 and 7) $\mathrm{km} / \mathrm{h}$. Each sub plot includes sub-sub plots, which involved three levels of tires air pressure (50, 100 and 150) $\mathrm{kPa}$. The sorghum crop (fresh forage) planted in May to October 2018 (one season) by seeder machine, with a rate of $60 \mathrm{~kg} / \mathrm{ha}$ and harvested in two cuts as a fresh forage. Noting that the tracks of tractor wheels on the soil surface fixed during the implementation of the research treatments for both the traditional and conservative agriculture.

\section{Measurements:}

\section{Fuel consumption rate:}

Fuel consumption per unit time was determined by measuring the volume of fuel consumed during operation time. It was calculated using the fuel meter equipment as shown in Figure (1). The length of line, which marked by the marker tool on the paper sheet represents the fuel consumption. The fuel meter was calibrated prior and the volume of fuel was determined accurately.
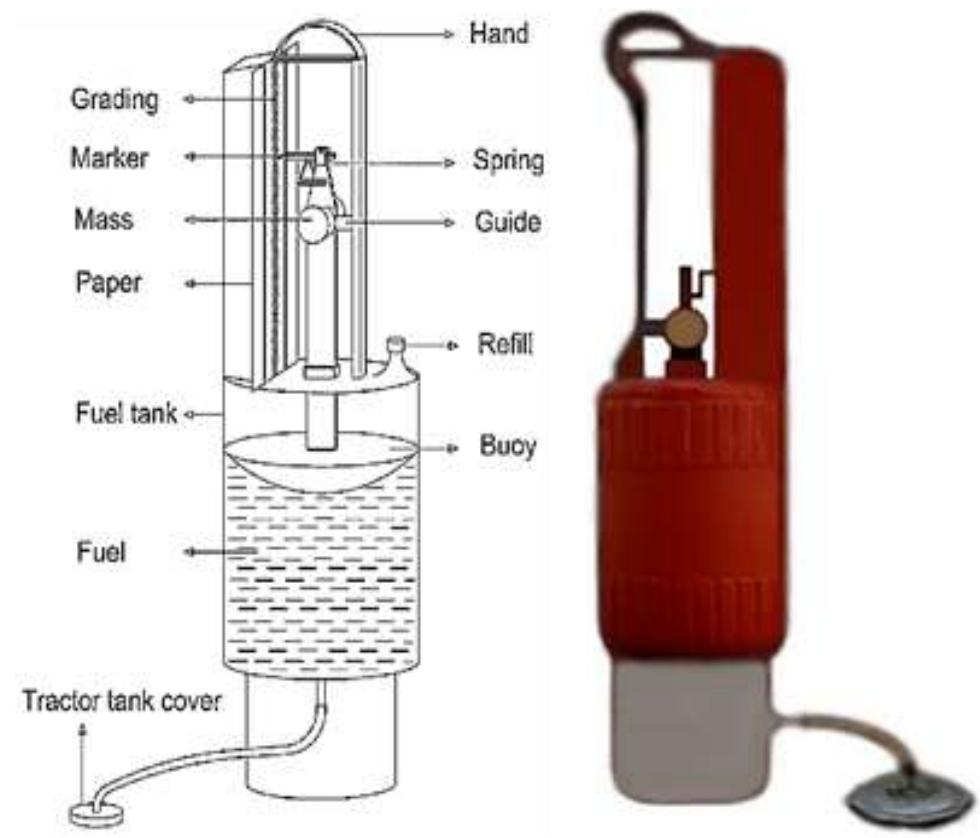

Figure 1:- Fuel meter for measuring fuel consumption. 


\section{Tractor wheel slippage:}

Slip percentages were calculated using the standard method of measuring distances traveled with and without load for a certain number of wheel revolutions.

\section{Rolling resistant:}

Rolling resistant was measured by hydraulic dynamometer, which, coupled between the two tractors with the attaching the machine while the machine lifted. A considerable number of readings were taken at a time interval 10 seconds to obtain an accurate average of rolling resistant.

\section{Soil bulk density:}

Soil bulk density was measured by a core sample according to Klute, (1986) method. Surface soil samples were (0$20 \mathrm{~cm}$ ) randomly taken from each treatment.

\section{Soil penetration resistance:}

Soil penetration resistance was measured by a Japanese cone index penetrometer model, (SR-2, DIK-500).

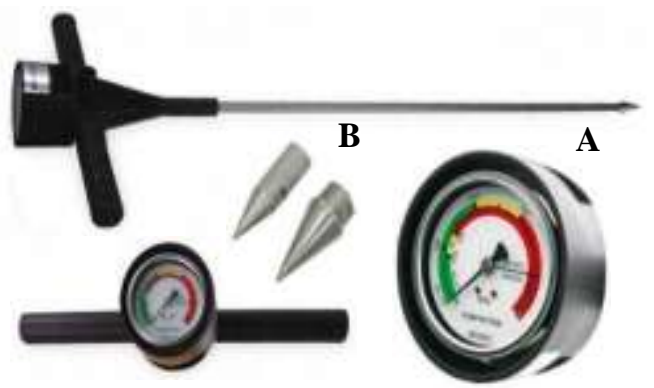

Probe length (In.) $\quad 30$

Probe Dia. (In.) $\quad 0.5$

Probe Material Steel

Pressure Range (PSI) $\quad 0$ to 500

Figure 2:- Standard vertical cone penetrometer.

A: Green testing range (0-200 psi): good growing conditions, yellow testing range (200-300 psi): fair growing conditions and red testing range (300 psi and above): poor growing conditions.

B: The small tip used for firm soil and the larger tip.

\section{Average infiltration rate:}

Infiltration characteristics of the studied soil was determined in the field by using a local made double ring (cylinder infiltrometer). The two cylinders were $30 \mathrm{~cm}$ deep and formed of steel sheet of $5 \mathrm{~mm}$ thickness which allow the cylinders to enter the soil with little disturbance. The inner cylinder, from which the infiltration measurements were taken, was $30 \mathrm{~cm}$ in diameter. The outer cylinder, which used to form the buffer pond was $60 \mathrm{~cm}$ in diameter. The double ring hammered into the soil to a depth of $15 \mathrm{~cm}$. Care was taken to keep the installation depth of the cylinder the same in all experiments. Average infiltration rates were calculated byKostiakov equation, (1932): $\mathrm{I}=60 \mathrm{c} \mathrm{T}^{\mathrm{m}-1}$ Where: $\mathrm{I}=$ average infiltration rate $(\mathrm{cm} / \mathrm{h}), \mathrm{C}$ and $\mathrm{m}=$ constants depend on soil properties and initial condition and $\mathrm{T}$ $=$ the time after infiltration started (min).

\section{Soil surface sinkage:}

Soil surface sinkage was measured using a profile meter; this consisted of a set of vertical metal rods, spaced at $2.5 \mathrm{~cm}$ intervals, sliding through a $100 \mathrm{~cm}$ long steel tube. The tube was placed across the wheel tracks perpendicular to the direction of travel and the rods were allowed to fall to conform to the shape of the depression (Carman, 1994).

\section{Soil layers deformation:}

Soil layers deformation was determined by an image processing technique. Plastic rods of different colors were buried in a horizontal plane to the right and left of the wheel track axis at three different soil depths $(7,14$ and $21 \mathrm{~cm})$ at $7 \mathrm{~cm}$ depth intervals. After passing of the tractor wheel a hole was dug and a photograph was taken of the rods. The coordinates of the rods were obtained using a global lab image program. For each rang of depth mean of displacement values in the vertical axis of rods was calculated (Kural, 1998).

All previous measurements were taken for the areas where the tractor wheels traffic and the areas that it did not traffic to make a comparison between the search parameters.

\section{Results and Discussion:-}




\section{Effect of study treatments on fuel consumption rate, tractor wheel slippage and rolling resistance:}

The results in Figure (3) showed the effect of different study treatments on fuel consumption rate, rolling resistance and tractor wheel slippage, where increasing soil moisture content (SMC) from $15 \%$ to $25 \%$, the fuel consumption rate and rolling resistance decreased about of $21 \%$ and 59\%, respectively but caused increasing tractor wheel slippage about of $68 \%$ in traditional agriculture system. Also in the conservation agriculture system, the results indicated to decrease fuel consumption rate and rolling resistance about of $31 \%$ and $51 \%$ respectively and increasing tractor wheel slippage about of $108 \%$. These results can be explaining by the fact that increasing soil moisture content weakens the bonding forces between soil particles. In addition, the results showed that when increasing the tractor forward speed (TFS) from 3 to $7 \mathrm{~km} / \mathrm{h}$ the fuel consumption rate and tractor wheel slippage increased about of 55\% and $40 \%$ respectively, and rolling resistance decreased about of $25 \%$ in the traditional agriculture system. However, in the conservation agriculture system, fuel consumption rate and wheel slippage increased about of $84 \%$ and $83 \%$, respectively, and rolling resistance decreased about of $21 \%$. The decreasing in tire air pressure of tractor (TAP) from $150 \mathrm{kPa}$ to $50 \mathrm{kPa}$ fuel consumption rate and rolling resistance increased about of $17 \%$ and $11 \%$ respectively but tractor wheel slippage decreased about of $21 \%$ in the traditional agriculture system. The increasing percentage of fuel consumption rate and rolling resistance about of $21 \%$ and $8 \%$, respectively, and the wheel slippage decreased about of $30 \%$ in the conservation agriculture system. These results because when the tire air pressure of tractor decreased the contact area increased between tire and soil surface, which caused increasing soil friction resistance to tractor tire. In general, the results showed that the power requirements were low in the conservation agriculture system compared to the traditional agriculture system. Under conservation agriculture system, fuel consumption rate, tractor wheel slippage and rolling resistance decreased about of $72 \%, 75 \%$ and $38 \%$, respectively compared to traditional agriculture system. These results because the mechanization process in conservation agriculture system limited to direct planting without tillage compared to traditional agriculture system, which includes the operations of planting and tillage (two passes).

\section{Effect of study treatments on some soil physical properties:}

Figure (4) showed the effect of different study treatments on soil bulk density, soil penetration resistance and average infiltration rate. Increasing of soil moisture content from $15 \%$ to $25 \%$ caused increasing soil compaction in traffic zones of tractor wheel. These reflected on increasing of soil bulk density and soil penetration resistance about of 9\%,39\% respectively, but average infiltration rate decreases about of 36\% in traditional agriculture system, while in conservation agriculture system were about of $8 \%, 20 \%$ and $45 \%$ respectively. As shown in Table (2) increasing of soil moisture content from $15 \%$ to $25 \%$ led to increase the soil surface sinckage in the traditional agriculture system and conservation agriculture system about of $38 \%$ and $48 \%$ respectively. In addition, the soil layers deformation at the soil depths of $7 \mathrm{~cm}, 14 \mathrm{~cm}$ and $21 \mathrm{~cm}$ increased about of $38 \%, 77 \%$ and $93 \%$ respectively in traditional agriculture system and about of $29 \%, 59 \%$ and $75 \%$, respectively in conservation agriculture system. These results can be explaining by the fact that when increasing the soil moisture content weakens of bonding force between the soil particles, thus reducing the soil resistance to compaction. The results showed that when the tractor speed increased from 3 to $7 \mathrm{~km} / \mathrm{h}$, the soil bulk density and soil penetration resistance decreased about of $11 \%, 15 \%$ respectively, but the average infiltration rate increases about of $35 \%$. However, these percentages in the conservation agriculture system were about of $7 \%, 12 \%$ and $39 \%$, respectively. Also led to decreases soil surface sinckage in traditional agriculture system and conservation agriculture system about of $17 \%$ and $31 \%$ respectively. While, soil layers deformation decreases at the soil depths of $7 \mathrm{~cm}, 14 \mathrm{~cm}$ and $21 \mathrm{~cm}$ about of $23 \%, 39 \%$ and $37 \%$ respectively, in traditional agriculture system and about of $24 \%, 31 \%$ and $39 \%$, respectively in conservation agriculture system. These results can be explaining that when the tractor forward speed increased this led to decreased contact duration between soil surface and tractor wheel which caused reduction of soil compaction. On other hand, when the air pressure of the tractor tire reduces from 150 to $50 \mathrm{kPa}$, this decreased soil compaction. Which rpresented as a decreasing both of soil bulk density and penetration resistance about of $8 \%$ and $14 \%$ respectively, but average infiltration rate increased at the traffic zones of tractor wheel about of $20 \%$, these percentages in the conservation agriculture system, were about of $7 \%, 11 \%$ and $24 \%$, respectively. Also caused decreasing soil surface sinckage in the traditional agriculture system and conservation agriculture system about of $20 \%$ and $46 \%$ respectively. While, soil layers deformation at the soil depths of $7 \mathrm{~cm}, 14 \mathrm{~cm}$ and $21 \mathrm{~cm}$ decreased about of $23 \%, 48 \%$ and $67 \%$ respectively, in traditional agriculture system and about of $41 \%, 20 \%$ and $41 \%$, respectively in conservation agriculture system. These results due to, when the tire air pressure decreased this led to increase contact area between soil surface and tractor wheel, which caused reduction of soil compaction. The results showed that decreasing of soil bulk density and soil penetration resistance while increasing average infiltration rate in conservation agriculture system lower than traditional agriculture system about of $48 \%, 37 \%$ and $72 \%$, respectively. The data indicated that the surface sinckage and soil layers deformation decreased in conservation 
agriculture system about of $57 \%$ and $63 \%$ respectively, compared to traditional agriculture system these due to decrease in the number of machines and the number of machines passes on the soil surface in the conservation agriculture system compared to the traditional agriculture system.

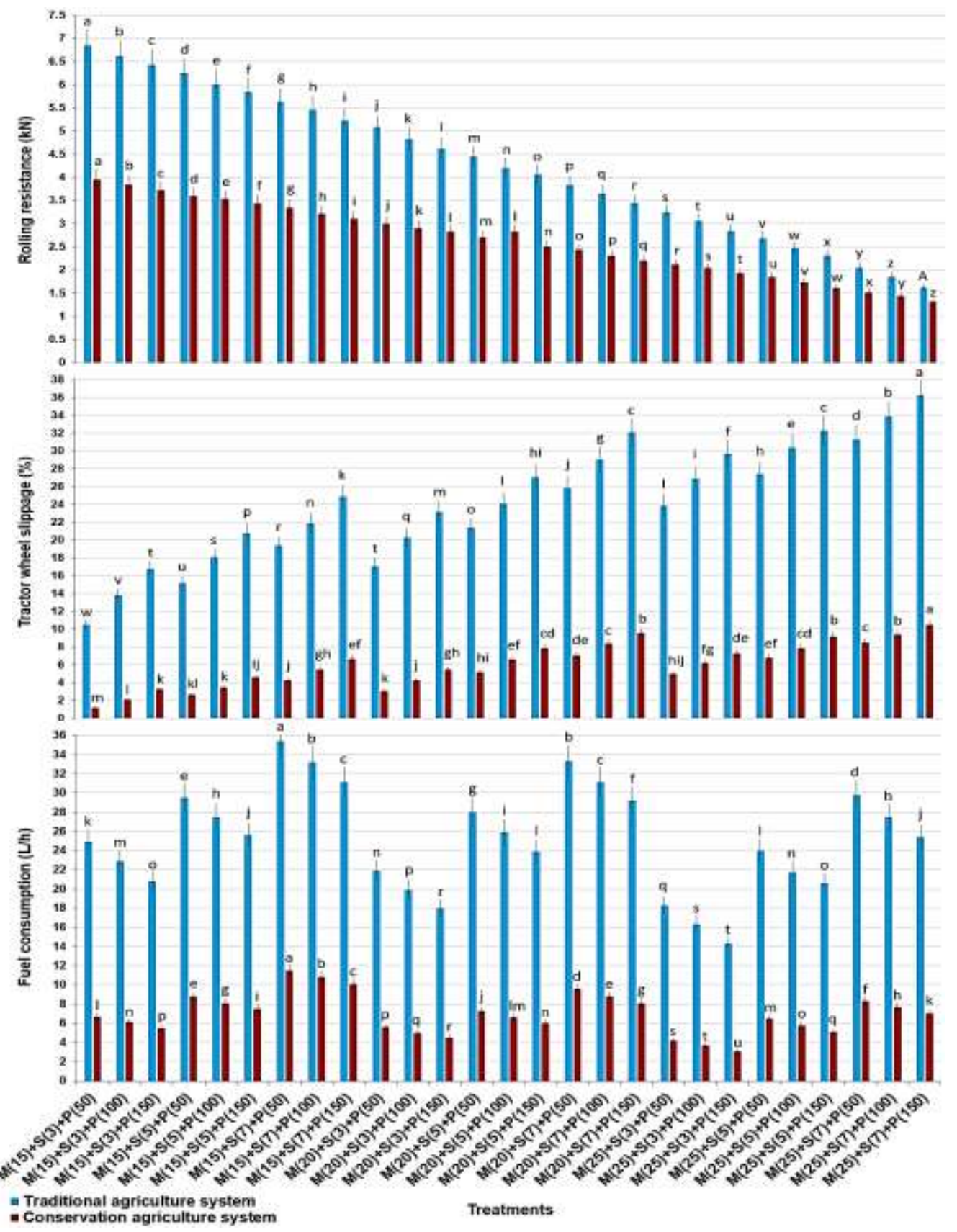

Figure 3:- Effect of study treatments (M - moisture content, \%, S - forward speed, $\mathrm{km} / \mathrm{h}$ and $\mathrm{P}$ - tire air pressure, $\mathrm{kPa}$ ) on fuel consumption rate, tractor wheel slippage and rolling resistance. Values followed by different letters are significantly different at $\mathrm{p}<0.05$ according to the LSD test. Error bars show the standard derivation among the repetitions $(\mathrm{n}=3)$. LSD for: fuel consumption rate $=0.29$, tractor wheel slippage $=0.3181$ and rolling resistance $=$ 0.0373 at traditional agriculture system. Fuel consumption rate $=0.1627$, tractor wheel slippage $=0.6278$ and rolling resistance $=1.0446$ at conservation agriculture system.

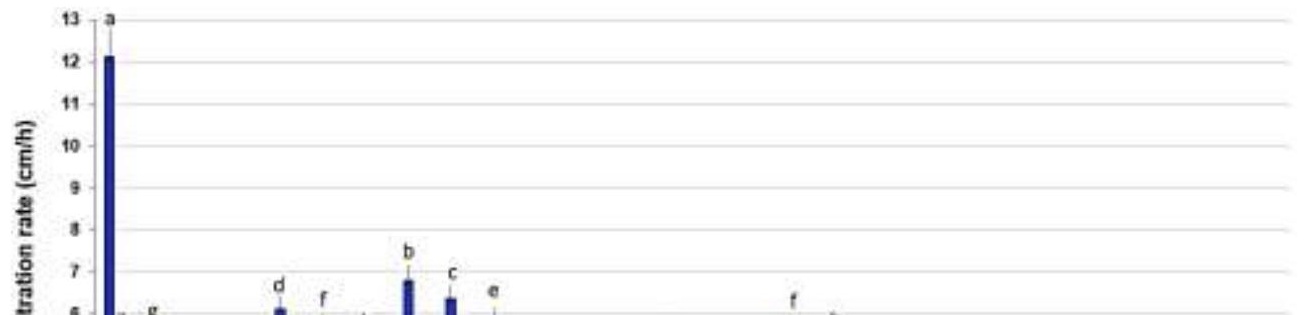


Figure 4:- Effect of different study treatments ( $\mathrm{M}$ - moisture content, \%, S - forward speed, $\mathrm{km} / \mathrm{h}$ and $\mathrm{P}$ - tire air pressure, $\mathrm{kPa}$ ) on soil bulk density, soil penetration resistance andaverage infiltration rate. Values followed by different letters are significantly different at $\mathrm{p}<0.05$ according to the LSD test. Error bars show the standard derivation among the repetitions $(n=3)$. LSD for: soil bulk density $=0.0295$, soil penetration resistance $=10.188$ and average infiltration rate $=0.0418$ at traditional agriculture system.soil bulk density $=0.031$, soil penetration resistance $=14.149$ and average infiltration rate $=0.0413$ at conservation agriculture system.

Table 2:- Effect of different study treatments on soil surface sinckage and soil layers deformation. 


\begin{tabular}{|c|c|c|c|c|c|c|c|c|c|c|}
\hline \multirow{3}{*}{ 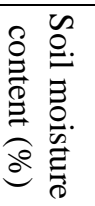 } & \multirow{3}{*}{ 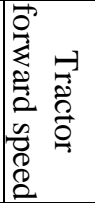 } & \multirow{3}{*}{ 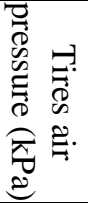 } & \multicolumn{4}{|c|}{ Traditional agriculture system } & \multicolumn{4}{|c|}{ Conservation agriculture system } \\
\hline & & & \multirow{2}{*}{$\begin{array}{c}\text { Soil } \\
\text { surface } \\
\text { sinkage } \\
(\mathrm{cm})\end{array}$} & \multicolumn{3}{|c|}{ Soil layers deformation $(\mathrm{cm})$} & \multirow{2}{*}{$\begin{array}{c}\text { Soil } \\
\text { surface } \\
\text { sinkage } \\
(\mathrm{cm})\end{array}$} & \multicolumn{3}{|c|}{ Soil layers deformation $(\mathrm{cm})$} \\
\hline & & & & $\begin{array}{r}7 \mathrm{~cm} \\
\text { depth }\end{array}$ & $\begin{array}{l}14 \mathrm{~cm} \\
\text { depth }\end{array}$ & $\begin{array}{l}21 \mathrm{~cm} \\
\text { depth }\end{array}$ & & $\begin{array}{r}7 \mathrm{~cm} \\
\text { depth }\end{array}$ & $\begin{array}{l}14 \mathrm{~cm} \\
\text { depth }\end{array}$ & $\begin{array}{l}21 \mathrm{~cm} \\
\text { depth }\end{array}$ \\
\hline \multirow[t]{9}{*}{15} & \multirow[t]{3}{*}{3} & 50 & $10.52^{r}$ & $5.43^{\mathrm{m}}$ & $2.82^{\mathrm{n}}$ & $1.17^{\mathbf{n}}$ & $4.19^{9}$ & $3.12^{\mathrm{k}}$ & $1.45^{\mathrm{m}}$ & $0.41^{\mathrm{k}}$ \\
\hline & & 100 & $11.68^{\mathrm{n}}$ & $6.21^{\mathrm{ij}}$ & $3.67^{\mathrm{k}}$ & $1.51^{\mathrm{k}}$ & $5.2^{1}$ & $3.77^{\mathrm{r}}$ & $1.57^{\mathrm{k}}$ & $0.52^{\mathrm{i}}$ \\
\hline & & 150 & $12.85^{\mathrm{j}}$ & $7.1^{\mathrm{f}}$ & $4.51^{\mathrm{g}}$ & $2^{\mathrm{h}}$ & $6.26^{\mathrm{T}}$ & $4.42^{\mathrm{b}}$ & $1.72^{\mathrm{hi}}$ & $0.64^{\mathrm{fg}}$ \\
\hline & \multirow[t]{3}{*}{5} & 50 & $9.45^{t}$ & $4.56^{\mathrm{p}}$ & $2.11^{\mathrm{p}}$ & $0.74^{\mathrm{p}}$ & $3.27^{\mathrm{t}}$ & $2.31^{\circ}$ & $1.12^{\mathrm{q}}$ & $0.32^{1}$ \\
\hline & & 100 & $10.61^{\mathrm{q}}$ & $5.33^{\mathrm{n}}$ & $2.93^{\mathrm{m}}$ & $1.13^{\mathrm{n}}$ & $4.18^{\mathrm{q}}$ & $2.97^{1}$ & $1.25^{\mathrm{p}}$ & $0.44^{\mathrm{jk}}$ \\
\hline & & 150 & $9.77^{\mathrm{s}}$ & $6.14^{\mathrm{jk}}$ & $3.75^{\mathrm{k}}$ & $1.55^{\mathrm{k}}$ & $5.23^{\mathrm{kT}}$ & $3.51^{j}$ & $1.36^{\circ}$ & $0.57^{\mathrm{h}}$ \\
\hline & \multirow[t]{3}{*}{7} & 50 & $8.32^{\mathbf{u}}$ & $3.78^{\mathrm{s}}$ & $1.26^{\mathrm{q}}$ & $0.35^{\mathrm{q}}$ & $2.15^{\mathrm{v}}$ & $1.55^{\mathrm{q}}$ & $0.73^{t}$ & $0.21^{\mathrm{m}}$ \\
\hline & & 100 & $9.51^{t}$ & $4.43^{\mathbf{q}}$ & $2.1^{\mathrm{p}}$ & $0.73^{\mathrm{p}}$ & $3.2^{\mathrm{u}}$ & $1.95^{\mathrm{p}}$ & $0.84^{\mathrm{s}}$ & $0.33^{\mathrm{I}}$ \\
\hline & & 150 & $10.73^{p}$ & $5.12^{\circ}$ & $2.95^{\mathrm{m}}$ & $1.24^{\mathrm{m}}$ & $4.11^{\mathrm{r}}$ & $2.51^{\mathrm{n}}$ & $0.92^{r}$ & $0.45^{\mathrm{j}}$ \\
\hline \multirow[t]{9}{*}{20} & \multirow[t]{3}{*}{3} & 50 & $12.17^{1}$ & $6.51^{\mathrm{h}}$ & $3.95^{\mathrm{j}}$ & $1.68^{\mathrm{j}}$ & $5.31^{\mathrm{j}}$ & $3.11^{\mathrm{k}}$ & $1.86^{\mathrm{g}}$ & $0.65^{\mathrm{efg}}$ \\
\hline & & 100 & $13.19^{\mathrm{i}}$ & $7.32^{\mathrm{e}}$ & $4.77^{\mathrm{e}}$ & $2.11^{\mathrm{g}}$ & $6.2^{\mathrm{g}}$ & $3.71^{\mathrm{g}}$ & $1.97^{\mathrm{f}}$ & $0.78^{\mathrm{d}}$ \\
\hline & & 150 & $14.22^{\mathrm{f}}$ & $6.1^{\mathrm{k}}$ & $5.62^{\mathrm{c}}$ & $2.55^{\mathrm{d}}$ & $7.21^{\mathrm{c}}$ & $4.17^{\mathrm{c}}$ & $2.1^{d}$ & $0.86^{\mathbf{c}}$ \\
\hline & \multirow[t]{3}{*}{5} & 50 & $11.1^{\mathrm{o}}$ & $5.35^{\mathrm{n}}$ & $3.27^{1}$ & $1.24^{\mathrm{m}}$ & $4.35^{\circ}$ & $2.51^{\mathrm{n}}$ & $1.63^{\mathrm{j}}$ & $0.53^{\mathrm{i}}$ \\
\hline & & 100 & $12.21^{1}$ & $6^{1}$ & $3.94^{j}$ & $1.65^{j}$ & $5.24^{\mathrm{k}}$ & $3.14^{\mathrm{k}}$ & $1.75^{\mathrm{h}}$ & $0.65^{\mathrm{efg}}$ \\
\hline & & 150 & $13.4^{\mathrm{h}}$ & $5.26^{\mathrm{n}}$ & $4.68^{r}$ & $2.12^{\mathrm{g}}$ & $6.3^{\mathrm{e}}$ & $3.61^{i}$ & $1.88^{\mathrm{g}}$ & $0.78^{\mathrm{d}}$ \\
\hline & \multirow[t]{3}{*}{7} & 50 & $9.81^{\mathrm{s}}$ & $4.16^{\mathrm{r}}$ & $2.51^{\circ}$ & $0.81^{\circ}$ & $3.51^{\mathrm{s}}$ & $1.94^{\mathrm{p}}$ & $1.41^{\mathrm{n}}$ & $0.42^{\mathrm{k}}$ \\
\hline & & 100 & $11.12^{\circ}$ & $5.97^{1}$ & $3.33^{1}$ & $1.26^{\mathrm{m}}$ & $4.49^{\mathrm{n}}$ & $2.47^{\mathrm{n}}$ & $1.56^{\mathrm{k}}$ & $0.54^{\mathrm{i}}$ \\
\hline & & 150 & $12.3^{\mathbf{k}}$ & $6.75^{\mathrm{g}}$ & $4.17^{i}$ & $1.67^{j}$ & $5.41^{\mathrm{i}}$ & $3.13^{k}$ & $1.68^{i}$ & $0.67^{\mathrm{ef}}$ \\
\hline \multirow[t]{9}{*}{25} & \multirow[t]{3}{*}{3} & 50 & $13.91^{\mathrm{g}}$ & $7.63^{d}$ & $5.13^{d}$ & $2.21^{\mathrm{f}}$ & $6.22^{\mathrm{g}}$ & $3.92^{\mathrm{e}}$ & $2.27^{\mathrm{c}}$ & $0.81^{\mathrm{d}}$ \\
\hline & & 100 & $15.33^{\mathrm{c}}$ & $8.43^{\mathrm{b}}$ & $5.85^{\mathrm{b}}$ & $2.64^{\mathrm{c}}$ & $7.3^{\mathbf{b}}$ & $4.41^{\mathrm{b}}$ & $2.55^{\mathrm{b}}$ & $0.96^{\mathrm{b}}$ \\
\hline & & 150 & $16.81^{\mathrm{a}}$ & $9.35^{\mathrm{a}}$ & $6.61^{\mathrm{a}}$ & $3^{\mathbf{a}}$ & $8.17^{\mathrm{a}}$ & $4.93^{\mathrm{a}}$ & $2.87^{\mathrm{a}}$ & $1.1^{\mathrm{a}}$ \\
\hline & \multirow[t]{3}{*}{5} & 50 & $12.78^{j}$ & $6.55^{\mathrm{h}}$ & $4.46^{\mathrm{gh}}$ & $1.8^{\mathrm{i}}$ & $5.11^{\mathrm{m}}$ & $3.13^{k}$ & $1.72^{\mathrm{hi}}$ & $0.63^{\mathrm{g}}$ \\
\hline & & 100 & $14.73^{\mathrm{d}}$ & $7.31^{\mathrm{e}}$ & $5.11^{d}$ & $2.27^{\mathrm{e}}$ & $6.2^{\mathrm{g}}$ & $3.65^{\mathrm{h}}$ & $1.87^{\mathrm{g}}$ & $0.78^{\mathrm{d}}$ \\
\hline & & 150 & $15.8^{\mathbf{b}}$ & $8.12^{\mathrm{c}}$ & $5.83^{b}$ & $2.75^{b}$ & $7.15^{\mathrm{d}}$ & $4.11^{\mathrm{d}}$ & $2.05^{\mathrm{e}}$ & $0.87^{\mathrm{c}}$ \\
\hline & \multirow[t]{3}{*}{7} & 50 & $11.93^{\mathrm{m}}$ & $5.48^{\mathrm{m}}$ & $3.75^{k}$ & $1.41^{\top}$ & $4.23^{\mathrm{p}}$ & $2.61^{\mathrm{m}}$ & $1.26^{\mathrm{P}}$ & $0.41^{\mathrm{k}}$ \\
\hline & & 100 & $13.12^{\mathrm{i}}$ & $6.26^{\mathrm{i}}$ & $4.41^{\mathbf{h}}$ & $1.82^{\mathrm{i}}$ & $5.26^{\mathrm{k}}$ & $3.12^{\mathrm{k}}$ & $1.38^{\mathrm{no}}$ & $0.55^{\mathrm{hi}}$ \\
\hline & & 150 & $14.32^{\mathrm{e}}$ & $7.1^{f}$ & $5.1^{\mathrm{d}}$ & $2.2^{f}$ & $6.14^{\mathrm{h}}$ & $3.7^{\mathrm{g}}$ & $1.5^{1}$ & $0.68^{\mathrm{e}}$ \\
\hline \multicolumn{3}{|c|}{ L.S.D } & 0.08 & 0.08 & 0.08 & 0.05 & 0.03 & 0.04 & 0.04 & 0.02 \\
\hline
\end{tabular}

Values followed by different letters are significantly different at $p<0.05$ according to the LSD test.

\section{Effect of study treatments on sorghum yield:}

Figure (5) showed the effect of the different study treatments on the sorghum crop yield (fresh forage). When soil moisture content increased from $15 \%$ to $25 \%$, the crop yield decreased in traffic zones of tractor wheel in traditional agriculture system and conservation agriculture system about of $22 \%$ and $15 \%$ respectively these results because increasing soil compaction in traffic zones when increasing soil moisture content. When tractor forward speed increased from 3 to $7 \mathrm{~km} / \mathrm{h}$ caused increasing sorghum yield in traditional agriculture system and conservation agriculture system about of $32 \%$ and $24 \%$ respectively these results because decreasing soil compaction in traffic zones when increasing tractor forward speed. When tire air pressure decreased from 150 to $50 \mathrm{kPs}$ sorghum yield increased in traditional agriculture system and conservation agriculture system about of $16 \%$ and $18 \%$ respectively. Data indicated to the sorghum yield increased in traditional agriculture system compared to conservation agriculture system about of 5\%. However, this result obtained when applied the conservation agriculture system for one season only but expect that the crop yield in the conservation agriculture system will be increase compared to the traditional agriculture system by continuing apply conservation agriculture system for more than two consecutive seasons. Results as shown in Figure (5) explained that the yield decreased for traditional agriculture system and conservation agriculture system about of $47 \%$ and $35 \%$ respectively in traffic zone compared to no-traffic zone.

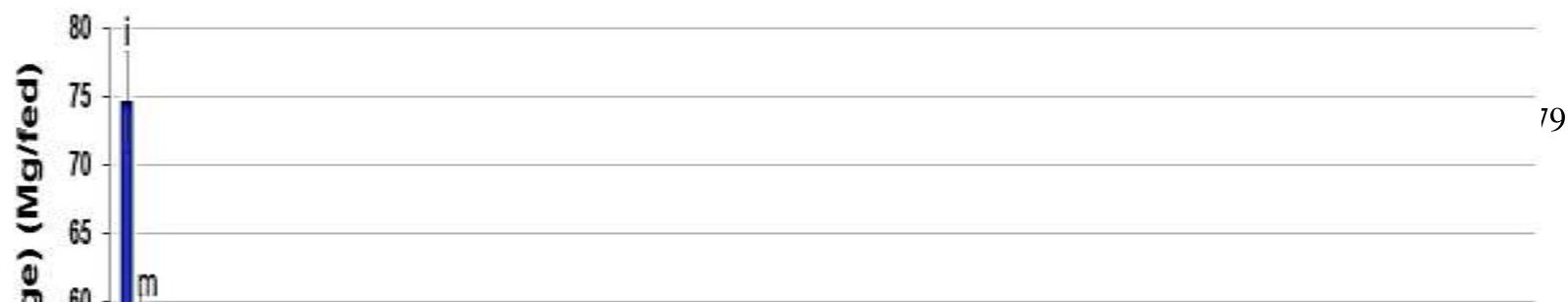


Figure 5:- Sorghum yield $\mathrm{Mg} / \mathrm{ha}$ under different study treatments $(\mathrm{M}$ - moisture content $\%, \mathrm{~S}$ - forward speed $\mathrm{km} / \mathrm{h}$, and $\mathrm{P}$ - tire air pressure, $\mathrm{kPa}$ ). Values followed by different letters are significantly different at $\mathrm{p}<0.05$ according to the LSD test. Error bars show the standard derivation among the repetitions $(n=3)$. LSD for: sorghum yield at traditional agriculture system $=1.4911$ and sorghum yield at conservation agriculture system $=1.4795$.

\section{Multiple linear regression relationships for different study treatments:}

Multiple linear regression relationships were determined for the effect of the different study treatments: soil moisture content (SMC), tractor forward speed (TFS) and tire air pressure of the tractor (TAP) on different measurements. In addition, determined the partial correlation factor (r) showed the effect and direction of each study treatment as shown in Table (3).

Table 3:- Multiple linear regression for effect of study treatments on different measurements.

\begin{tabular}{|c|c|c|}
\hline Measurements & \multicolumn{2}{|c|}{ Multiple linear regression } \\
\hline $\mathrm{Y}=$ & $\mathrm{a}_{1} \mathrm{SMC}+\mathrm{a}_{2} \mathrm{TFC}+\mathrm{a}_{3} \mathrm{TAP}+\mathrm{a}_{4}$ \\
\hline & Traditional agriculture system & Conservation agriculture system \\
\hline
\end{tabular}




\begin{tabular}{|c|c|c|c|c|c|c|c|c|c|c|c|c|}
\hline & \multicolumn{3}{|c|}{ Factors } & \multirow[t]{2}{*}{-} & \multirow[t]{4}{*}{$\mathrm{R}^{2}$} & \multicolumn{3}{|c|}{ Factors } & \multirow[t]{2}{*}{ - } & \multirow[t]{4}{*}{$\mathrm{R}^{2}$} \\
\hline & & & SMC & TFC & TAP & & & SMC & TFC & TAP & & \\
\hline \multicolumn{3}{|c|}{ Constants } & $a_{1}$ & $a_{2}$ & $\mathrm{a}_{3}$ & $a_{4}$ & & $\mathrm{a}_{1}$ & $a_{2}$ & $a_{3}$ & $a_{4}$ & \\
\hline \multicolumn{3}{|c|}{ Partial correlation factor } & $\mathrm{r}_{1}$ & $\mathrm{r}_{2}$ & $r_{3}$ & - & & $\mathrm{r}_{1}$ & $\mathrm{r}_{2}$ & $r_{3}$ & - & \\
\hline \multirow{2}{*}{\multicolumn{2}{|c|}{$\begin{array}{c}\text { Fuel } \\
\text { consumption } \\
(\mathrm{L} / \mathrm{h})\end{array}$}} & Constants & -0.589 & 2.742 & $\begin{array}{c}- \\
0.040\end{array}$ & 27.277 & \multirow[t]{2}{*}{$\begin{array}{c}0.9 \\
7\end{array}$} & -0.263 & 1.042 & $\begin{array}{c}- \\
0.013\end{array}$ & 8.310 & \multirow[t]{2}{*}{$\begin{array}{c}0.9 \\
6\end{array}$} \\
\hline & & $\begin{array}{c}\text { Partial } \\
\text { correlatio } \\
\mathrm{n} \text { factor }\end{array}$ & -0.97 & 0.99 & -0.96 & - & & -0.98 & 0.99 & -0.92 & - & \\
\hline \multirow{2}{*}{\multicolumn{2}{|c|}{$\begin{array}{c}\text { Tractor } \\
\text { wheel } \\
\text { slippage }(\%)\end{array}$}} & Constants & 1.230 & 2.011 & 0.057 & 16.137 & \multirow{2}{*}{$\begin{array}{c}0.9 \\
8\end{array}$} & 0.410 & 0.889 & 0.023 & -8.930 & \multirow{2}{*}{$\begin{array}{c}0.9 \\
8\end{array}$} \\
\hline & & $\begin{array}{c}\text { Partial } \\
\text { correlatio } \\
\mathrm{n} \text { factor }\end{array}$ & 0.99 & 0.98 & 0.96 & - & & 0.98 & 0.97 & 0.94 & - & \\
\hline \multirow{2}{*}{\multicolumn{2}{|c|}{$\begin{array}{c}\text { Rolling } \\
\text { resistance } \\
(\mathrm{kN})\end{array}$}} & Constants & -0.357 & -0.300 & $\overline{-}$ & 13.303 & \multirow[t]{2}{*}{$\begin{array}{c}0.9 \\
9\end{array}$} & -0.180 & -0.179 & $\overline{-}$ & 7.378 & \multirow[t]{2}{*}{$\begin{array}{c}0.9 \\
5\end{array}$} \\
\hline & & $\begin{array}{c}\text { Partial } \\
\text { correlatio } \\
\mathrm{n} \text { factor }\end{array}$ & -0.98 & -0.96 & -0.94 & - & & -0.97 & -0.85 & -0.82 & - & \\
\hline \multirow{2}{*}{\multicolumn{2}{|c|}{$\begin{array}{c}\text { Soil bulk } \\
\text { density } \\
\left(\mathrm{g} / \mathrm{cm}^{3}\right)\end{array}$}} & Constants & 0.015 & -0.047 & 0.002 & 1.560 & \multirow{2}{*}{$\begin{array}{c}0.9 \\
7\end{array}$} & 0.014 & -0.031 & 0.001 & 1.627 & \multirow{2}{*}{$\begin{array}{c}0.9 \\
8\end{array}$} \\
\hline & & $\begin{array}{c}\text { Partial } \\
\text { correlatio } \\
\text { n factor }\end{array}$ & 0.97 & -0.98 & 0.96 & - & & 0.99 & -0.98 & 0.95 & - & \\
\hline \multirow{2}{*}{\multicolumn{2}{|c|}{$\begin{array}{c}\text { Soil } \\
\text { penetration } \\
\text { resistance } \\
(\mathrm{kPa})\end{array}$}} & Constants & $\begin{array}{c}30.68 \\
9\end{array}$ & $\begin{array}{c}- \\
42.19 \\
4\end{array}$ & 1.429 & $\begin{array}{c}385.08 \\
3\end{array}$ & \multirow[t]{2}{*}{$\begin{array}{c}0.9 \\
8\end{array}$} & $\begin{array}{c}22.07 \\
8\end{array}$ & $\begin{array}{c}- \\
39.27 \\
8\end{array}$ & 1.394 & $\begin{array}{c}827.61 \\
1\end{array}$ & \multirow[t]{2}{*}{$\begin{array}{c}0.9 \\
8\end{array}$} \\
\hline & & $\begin{array}{c}\text { Partial } \\
\text { correlatio } \\
\text { n factor }\end{array}$ & 0.99 & -0.98 & 0.97 & - & & 0.99 & -0.98 & 0.97 & - & \\
\hline \multirow{2}{*}{\multicolumn{2}{|c|}{$\begin{array}{l}\text { Average } \\
\text { infiltration } \\
\text { rate }(\mathrm{cm} / \mathrm{h})\end{array}$}} & Constants & -0.206 & 0.338 & $\begin{array}{c}- \\
0.010\end{array}$ & 8.049 & \multirow[t]{2}{*}{$\begin{array}{c}0.9 \\
8\end{array}$} & -0.191 & 0.258 & $\begin{array}{c}- \\
0.009\end{array}$ & 6.626 & \multirow[t]{2}{*}{$\begin{array}{c}0.9 \\
9\end{array}$} \\
\hline & & $\begin{array}{c}\text { Partial } \\
\text { correlatio } \\
\text { n factor }\end{array}$ & -0.98 & 0.96 & -0.94 & - & & -0.99 & 0.97 & -0.95 & - & \\
\hline \multirow{2}{*}{\multicolumn{2}{|c|}{$\begin{array}{c}\text { Soil surface } \\
\text { sinkage }(\mathrm{cm})\end{array}$}} & Constants & 0.392 & -0.542 & 0.022 & 4.908 & \multirow{2}{*}{$\begin{array}{c}0.9 \\
5\end{array}$} & 0.200 & -0.488 & 0.020 & 1.725 & \multirow{2}{*}{$\begin{array}{c}0.9 \\
9\end{array}$} \\
\hline & & $\begin{array}{c}\text { Partial } \\
\text { correlatio } \\
\text { n factor }\end{array}$ & 0.97 & -0.91 & 0.92 & - & & 0.98 & -0.96 & 0.97 & - & \\
\hline & 7 & Constants & 0.201 & -0.418 & 0.013 & 2.984 & 0.9 & 0.083 & -0.349 & 0.011 & 2.228 & 0.9 \\
\hline 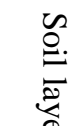 & $\begin{array}{c}\mathrm{cm} \\
\mathrm{dept} \\
\mathrm{h}\end{array}$ & $\begin{array}{c}\text { Partial } \\
\text { correlatio } \\
\text { n factor }\end{array}$ & 0.85 & -0.87 & 0.80 & - & 4 & 0.90 & -0.96 & 0.94 & - & 6 \\
\hline$\stackrel{9}{2}$ & 14 & Constants & 0.224 & -0.371 & 0.016 & -0.153 & 0.9 & 0.072 & -0.197 & 0.003 & 0.884 & 0.8 \\
\hline 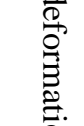 & $\begin{array}{c}\mathrm{cm} \\
\mathrm{dept} \\
\mathrm{h}\end{array}$ & $\begin{array}{c}\text { Partial } \\
\text { correlatio } \\
\text { n factor }\end{array}$ & 0.97 & -0.98 & 0.96 & - & 9 & 0.88 & -0.89 & 0.79 & - & 9 \\
\hline $\overrightarrow{9}$ & 21 & Constants & 0.108 & -0.205 & 0.009 & -0.289 & 0.9 & 0.032 & -0.069 & 0.002 & 0.064 & 0.9 \\
\hline$\widehat{\varrho}$ & $\begin{array}{c}\mathrm{cm} \\
\mathrm{dept} \\
\mathrm{h}\end{array}$ & $\begin{array}{c}\text { Partial } \\
\text { correlatio } \\
\text { n factor }\end{array}$ & 0.97 & -0.95 & 0.93 & - & 9 & 0.93 & -0.91 & 0.90 & - & 4 \\
\hline $\begin{array}{r}\text { Sor } \\
y\end{array}$ & $\begin{array}{l}\text { hum } \\
\text { ld }\end{array}$ & Constants & -0.997 & 2.714 & $\begin{array}{c}- \\
0.068 \\
\end{array}$ & 52.665 & $\begin{array}{c}0.9 \\
7\end{array}$ & -0.602 & 1.994 & $\begin{array}{c}- \\
0.073\end{array}$ & 47.078 & $\begin{array}{c}0.9 \\
7\end{array}$ \\
\hline & & $\begin{array}{c}\text { Partial } \\
\text { correlatio } \\
\mathrm{n} \text { factor }\end{array}$ & -0.96 & 0.98 & -0.97 & - & & -0.93 & 0.96 & -0.95 & - & \\
\hline
\end{tabular}




\section{Conclusions:-}

The following conclusions illustrate effect of the study treatments, (soil moisture content, tractor forward speed and tire air pressure of tractor wheel) on the soil compaction resulting from the tractor traffic, under the traditional agriculture system and the conservation agriculture system of sandy loam soil:

1. Increasing soil moisture content led to decrease fuel consumption, rolling resistance and increasing tractor wheel slippage in both of two systems of agriculture.

2. Increasing tractor forward speed led to increase the fuel consumption and tractor wheel slippage but led to decreasing rolling resistance.

3. Low air pressure in tractor wheels' tire led to increase the fuel consumption and rolling resistance but led to decreasing tractor wheel slippage.

4. Soil compaction decreased when both of soil moisture content and tire air pressure decreased and tractor forward speed increased.

5. The yield of sorghum crop decreased by increasing soil compaction resulting from tractor traffic.

6. The soil compaction which resulting from tractor traffic on the soil surface was less in conservation agriculture system compared to traditional agriculture system which caused decreasing in sorghum yield was high in traditional agriculture system compared to conservation agriculture system.

7. The previous discussion showed that the conservative agriculture system is one of the most agriculture systems resistant to soil compression resulting from traffic of the tractor wheel.

8. Future studies shall focus on conducting this study for more than one agricultural season in order to demonstrate the ability of the conservation agriculture system to maintain higher productivity of crops than the traditional farming system.

\section{References:-}

1. Abebe, A.T., T. Tanaka and M. Yamazaki, (1989). Soil compaction by multiple passes of a rigid wheel relevant for optimization of traffic. J. Terramech., 26: 139-148.

2. Abu-Hamdeh, N.H. and R.C. Reeder, (2003). Measuring and predicting stress distribution under tractive devices in undisturbed soil. Biosys. Eng., 85: 493-502.

3. Alakukku, L., Weisskopf, P., Chamen, W.C.T., Tijink, F.G.J., van der Linden, J.P., Pires, S., Sommer, C. and G. Spoor, (2003). Preventionstrategies for field traffic-induced subsoil compaction: areview. Part 1. Machine/soil interactions. Soil Till. Res. 73, 145-160.

4. Allison, L.E and C.D. Moodie, (1965). Carbonate. In: Black, CA (ed.), Methods of Soil Analysis. Part II, American Society of Agronomy. Madison, Wisconsin, pp: 1379-1396.

5. Amir, I., G.S.V. Raghvan, E. McKyes and R.S. Broughton, (1976). Soilcompaction as a function of contactpressure and soil moisture content.Can. Agric. Eng. 18, 54-57.

6. Ansorge, D. and R.J., Godwin, (2008). The effect of tyres and a rubber track at high axel loads on soil Compaction-Part 2. Multi-axel machine studies. Biosystems Engineering 99, 338-347.

7. Arvidsson, J., (2001).Subsoil compactioncaused byheavy sugarbeetharvesters insouthernSwedenI. Soil physicalpropertiesand crop yield in sixfield experiments.Soil Till. Res., 60, 67-78.

8. Arvidsson, J. and T. Keller, (2007). Soil stress as affected by wheel load and tyre inflation pressure. Soil Till. Res. 96, 284-291.

9. Bailey, A.C., R.L. Raper, T.R. Way, E.C. Burt and C.E. Johnson, (1993). Soilstress under tractor tires at variousinflation pressures. Proceedings of11th International Conference of theISTVS, 1:276- 285. Lake Tahore, NV. USA. September 27-30.

10. Bauder, J.W., G.W. Randall, and J.B. Swan, (1981). Effect of four continuoustillage systems on mechanicalimpedance of a clay loam soil. SoilSci. Soc. Am. J. 45:802-806.

11. Bolling, I.H., (1986). How to predict soil compaction from agricultural tires. J. Terramechanics 22, 205-223.

12. Botta, G.F., Tolon Becerra and F., BelloraTourn, (2009). Effect of number of tractor passes on soil rut depth and compaction in two-tillage regime. Soil and Tillage Research, 103: 381-386

13. Busscher, W.J., (1990). Adjustment of flat-tipped penetration resistance data to a common water content. Transaction ASAE, 33, 519-524.

14. Carman, K., (1992). The investigation of effect on compaction of contact time in tire-soil interface. J. Agric. Faculty, University of Selcuk 2 (4), 49-58 (in Turkish).

15. Carman, K., (1994). Tractor forward velocity and tire load effects on soil compaction. J. Terramechanics. 31, 1120. 
16. Carman, K., (2002). Compaction characteristics of towed wheel on clay loam in a soil bin. Soil \& Tillage Research 65, 37-43.

17. Carter, L.M., B.D. Meek and E.A. Rechel, (1991). Zone production system for cotton, soil response, Trans. ASAE 34, 354-360.

18. Carter, M.R., (1990). Relative measures of soil bulk density to characterize compaction in tillage studies on fine sandy loam. Can. J. Soil Sci., 70, 425-433.

19. Feldman and Domiers, (1970). Wheeled traffic effects on soil compaction and growth of wheat. Can. Agr. Eng. $12(1), 8-11$.

20. Flowers, M. and R. Lal, (1998). Axle load and tillage effect on soil physical properties and soybean grain yield on a mollicochraqualf in northwest Ohio, Soil Till. Res., 48, 21-35.

21. Grahn, M., (1991). Prediction of sinkage and rolling resistance for off the road vehicles considering penetration velocity. J. Terramechanics 28, 339-347.

22. Gupta, S.C., A. Hadas, W.B. Voorhees, W. Wolf, W.E. Larson andE.C. Schneider, (1985). Development of guides for estimating the ease of compaction of world soils. Univ. of Minnesota, St. Paul, MN-USA.

23. Hamza, M.A. and W.K. Anderson, (2003). Responses of soil properties and grain yield to deep riping and gypsum application in a compacted loamy sand soil contrasted with a sandy clay loam soil in Western Australia, Aust. J. Agr. Res., 53, 615-620.

24. Hamza, M.A. and W.K. Anderson, (2005). Soil compaction in cropping systems: a review of the nature, causes, and possible solutions. Soil Tillage Res. 82, 121-145.

25. Hettiaratchi, D.R.P., (1987). A critical state soil mechanics model for agricultural soils, Soil Use Manage., 3: 94-105.

26. Hill, R.L. and M. Meza-Montalvo, (1990). Long- term wheel traffic effects on soilphysical properties under different tillage systems. Soil Sci. Soc. Am. J., 54, 865-870.

27. Horn, R, T. Way and J. Rostek, (2001). Effect of repeated wheeling on stress/strain properties and ecological consequences in structured arable soils, Revista de la CienciadelSueloyNutricion Vegetal, 1, 34-40.

28. International Institute of Rural Reconstruction and Africa Conservation Tillage Network (IIRR and ACT), (2005). Conservation agriculture: a manual for farmers and extension workers in Africa. Nairobi: IIRR.

29. Jakobsen, B.F. and A. Dexter, (1989). Prediction of soil compaction under pneumatic tyres. J. Terramechanics 26 (3), 107-19.

30. Kirby, J.M. and G. Kirchhoff, (1990). The compaction process and factors affecting soil compactibility. In: Hunter, M.N., Paull, C.J., Smith, G.D. (Eds.), Proceedings of Queensland Department of Primary Industries Soil Compaction Workshop, Toowoomba, Australia, pp. 28-31.

31. Klute, A., (1986). Methods of Soil Analysis. Part (1): Physical and Mineralogical Methods. No. 9 in the Agronomy Series. Amer. Soc. of Agron. \& Soil Sci. Soc. of America (Publisher). Second Edition. Madison, Wisconsin, USA.

32. Kostiakov, A.N., (1932). On the dynamics of the coefficients of water percolation in soils and of the necessity of studying it from a dynamic point of view for purposes of amelioration. Trans., 6th Committee Inter. Soc. Soil Sci., pp.17-21.

33. Kulli, B., Gysi, M. and H. Fluhler, (2003). Visualizing soil compactionbased on flow pattern analysis. Soil Till. Res. 70, 29-40.

34. Kural, H., (1998). The rolling resistance of 7.50-16 free-rolling tires used in agricultural machinery and their effects on soil compaction. D.Sc. Thesis. Graduate School of Natural and Applied Sciences of Selcuk University, Konga, Turkey (in Turkish).

35. Lal, R., (1996). Axle load and tillage effects on soil degradation and rehabilitation in Western Nigeria. I. Soil physical and hydrological properties. Land Degradation Review 7, 19-45.

36. Marsili, A., P. Servadio, M. Oagliai and N. Vignozzi, (1998). Changes of somephysical properties of a clay soil following passage of rubberand metal-tracked tractors. Soil and Tillage Res. 49 (3), 185-199.

37. McKyes, E., (1985). Soil Cutting and Tillage. ElsevierScience Publishing Company Inc. New York. USA.

38. Mead, J.A., A.L. Palmer and K. Y. Chan, (1992). Effect of seedbedconditions on sowing pointperformance. Soil and Tillage Res.22 (1-2), 13-25.

39. Meek, B.D., E.R. Rechel, L.M. Carter and W.R. DeTar, (1992). Bulk density of a sandy loam: Traffic, tillage, and irrigation-method Effects. Soil Sci. Soc. Am. J. 56, 562-565.

40. Meek, B.D., E.R. Rechel, L.M. Carter, and W.R. DeTar, (1988). Soilcompaction and its effect on alfalfain zone production systems. Soil Sci. A. J. 51, 230-236.

41. Ohu, J.O., E.I. Ekwue and O.A. Folorunco, (1994). The effect of addition of organic matter on the compaction of a vertisol from northern Nigeria, Soil Technol., 7, 155-162. 
42. Pagliai, M., Marsili, A., Servadio, P., Vignozzi, N. and S. Pellegrini, (2003). Changes in some physical properties of a clay soil inCentral Italy following the passage of rubber tracked andwheeled tractors of medium power. Soil Till. Res. 73, 119-129.

43. Patel, M.S. and N.T. Singh, (1981). Changes in bulk density and water intake rate of coarse textural soil in relation to different levels of compaction. J. Ind. Soc. Soil Sci.29, 110-112.

44. Patel, S. K. and I. Mani, (2011). Effect of multiple passes of tractor with varying normal load on subsoil compaction. Journal of Terramechanics 48, 277-284.

45. Phillips, R.E. and D. Kirkham, (1962). Soil compaction in the field and corn growth. Agron. J., 54, $29-34$.

46. Raper, R.L. and D.W., Reeves, (2007). In-Row subsoiling and controlled traffic effects on coastal plain soils. Transactions of the ASABE 50 (4), 1109-1115, ISSN 0001-2351.

47. Silva, V.R., D.J. Reinert and J.M. Reichert, (2000). Soil strength as affected by combine wheel traffic and two soil tillage systems, Ciencia Rural., 30, 795-801.

48. Singh, K. K, T.S. Colvin, D.C. Erbach and A.Q. Mughal, (1992). Tilth Index: An approach to quantifying soil tilth. Transactions of the A.SAE 35 (6)1777-1785.

49. Soane, B.D., C. Van Ouwerkerk and Editors, (1994). Soil Compaction in Crop Production, Developments in Agricultural Engineering Series vol. 11, Elsevier Science, Amsterdam, The Netherlands, pp: 662.

50. Swan, J.B., J.F. Moncrief and W.B. Voorhees, (1987). Soil compaction causes, effect and control. Ext. Publ. AG-BU-3115. Minnesota Ext.Service, Univ. of Minnesota, St. Paul, MN.

51. Tullberg, J. N., M.N. Hunter, C.J. Paull and G. D. Smith Editors, (1990). Proceedings of Queensland Department of Primary Industries Soil Compaction Workshop Toowoomba, Australia, Why control field traffic, 28, 13-25.

52. Way T.R. and T. Kishimoto, (2004). Interface pressures of a tractor drive tyre on structured and loose soils. Biosystems Eng. 87 (3), 75-86.

53. Zeleke, G., P.M.O., Owende, C.N. S., Canali and M. Ward, (2007). Predicting the pressure sinkage characteristics of two forest sites in Ireland using in-situ soil mechanical properties. Biosystems Engineering, 97, 267-281. 